\title{
Field investigations in the Precambrian terrain of the Thule district, North-West Greenland
}

\author{
Peter R. Dawes
}

The field mapping of the Precambrian crystalline basement and overlying Thule Group of the Thule district aimed at the production of a 1:500 000 map sheet between $75^{\circ} 15^{\prime} \mathrm{N}$ and $78^{\circ} \mathrm{N}$ was continued in July and August (fig. 5). The field work was split up, due to the varying availability of transport facilities, into three phases.

(1) The charter of a Bell 204 helicopter from Thule Air Base enabled mapping in western Inglefield Land, and in the nunatak terrain of Prudhoe Land and Melville Bugt.

(2) Investigation of the outer coast of western Melville Bugt was carried out with the aid of GGU cutter $K . J$. V. Steenstrup.

(3) Detailed stratigraphical work in the middle and upper part of the Thule Group was based on foot traverses from Thule Air Base.

During the shipborne phase the mapping work was carried out jointly with Jan C. Escher, while T. O. Frisch of the Geological Survey of Canada joined the field work for several days in July to further the comparative studies of the Thule Group in Greenland and Ellesmere Island already in progress.

\section{Precambrian crystalline basement \\ Inglefield Land}

The main rock types of south-west Inglefield Land have been reported on earlier (Dawes, 1972). In 1978 the investigations were extended as far north as Rensselaer Bugt $\left(78^{\circ} 40^{\prime} \mathrm{N}\right)$.

The basement forming the outer coast at Rensselaer Bugt, Force Bugt and along the coast to Cairn Pynt (fig. 5) is composed of a high-grade complex of red to brownish-weathering granites, granitic gneisses and basic rocks that are referred to the Etah meta-igneous complex - the type locality of which is to the south around Etah.

The rocks characteristically contain hypersthene with biotite and occasional garnet; blue quartz is typical. At Kap Inglefield the dominant rock type is a dark grey medium-grained enderbite, that in places is veined by a red-weathering charnockitic, often pegmatitic, late intrusion phase. Charnockitic gneisses, in places with large-scale banding, are derived from these rock types.

Thin tracts of quartz-rich gneisses and occasional garnet-amphibole calc-silicate rocks may represent relicts of the Etah Group. Inland from Rensselaer Bugt, tracts of light-weathering crystalline limestone make up an important part of the basement terrain and represent the extension of the E-W trending belts of the Etah Group mapped along the coast between Etah and Kap Hatherton (Dawes, 1972).

Prudhoe Land

Investigations were undertaken in the entire nunatak zone from Kap Alexander to the head of Inglefield Bredning. 


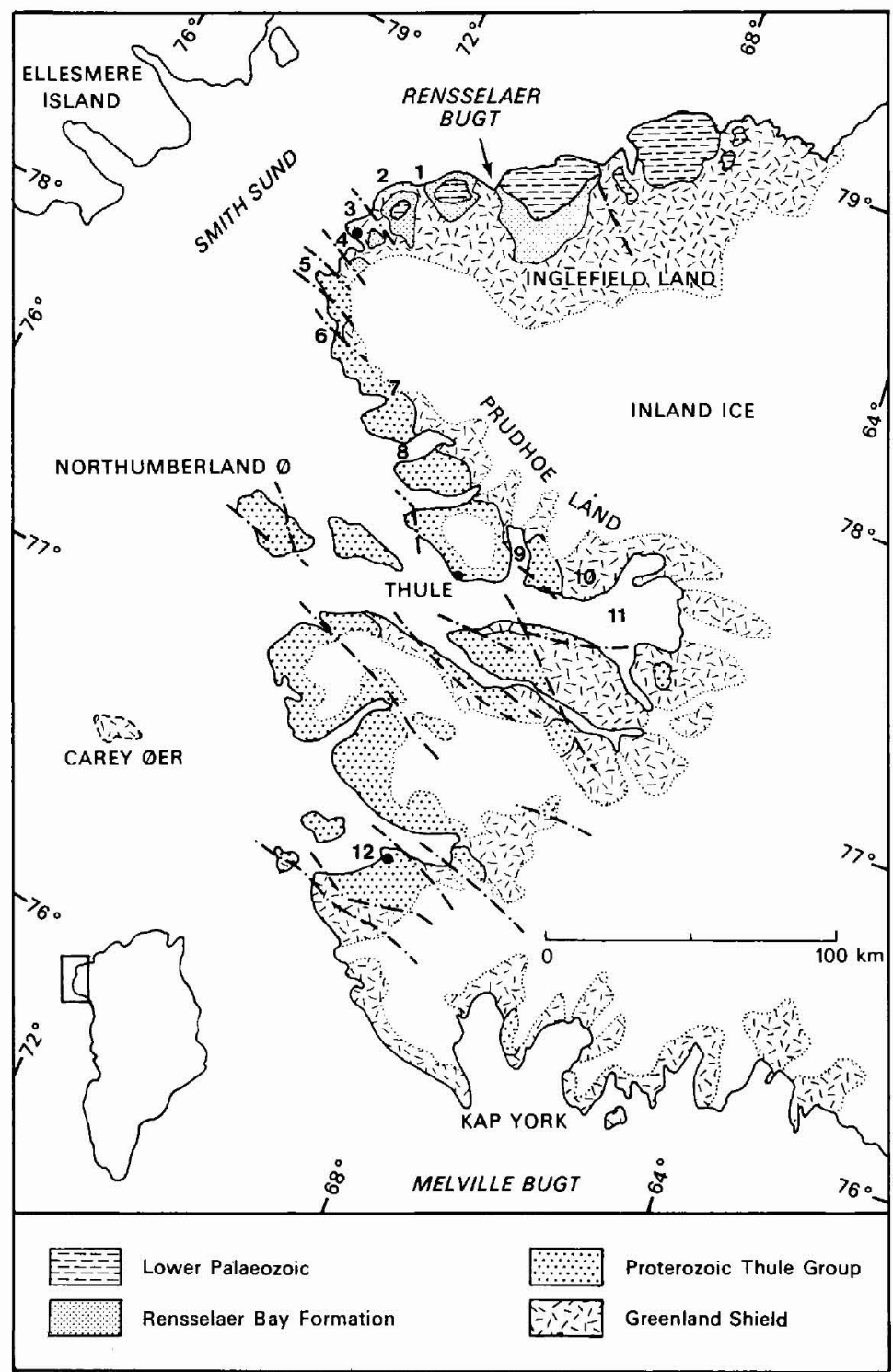

Fig. 5. Geological sketch map of the Thule District, North-West Greenland. 1: Force Bugt; 2: Kap Inglefield, Cairn Pynt; 3: Kap Hatherton, Hatherton Bugt; 4: Etah; 5: Kap Alexander, Dodge Gletscher; 6: Radcliffe Pynt, Sonntag Bugt; 7: Morris Jesup Gletscher; 8: Robertson Fjord; 9: Bowdoin Fjord, Sugarloaf; 10: Hubbard Gletscher; 11: Inglefield Bredning; 12: North Star Bugt, Dundas, Dundas Fjeld, Thule Air Base. 
The main part of the basement terrain of Prudhoe Land is composed of a high-grade gneiss complex composed of a variety of gneisses, granitic gneisses and foliated granites that form a monotonous succession without conspicuous marker horizons. In places the complex contains small areas of supracrustal rocks, mainly quartzites and quartz-rich schists and paragneisses, together with some basic schist units. Large areas of the complex have been metamorphosed in granulite facies with orthopyroxene, garnet and biotite as common minerals. Smaller areas of amphibolite-facies gneisses and basic rocks also occur, and in some places at least, these represent retrogressed units.

On the north-west side of Morris Jesup Gletscher at its head, supracrustal rocks, (hereby termed the Morris Jesup Gletscher supracrustals), form a shallowly dipping succession that from aerial photographs erroneously had been interpreted as part of the younger Thule Group. This succession is at least $400 \mathrm{~m}$ thick and it appears to be structurally uncomplicated being a single unit folded within the gneisses.

The main part of the succession is composed of predominantly rusty-weathering, metasediments with some darker, more resistent, hypersthene-bearing basic rock units of varying thickness and some basic schist layers. These basic rocks are of probable igneous origin and they vary from enderbite to pyroclasite with variation in quartz content; some contain garnet. The most prominent metasediments are garnet-mica-sillimanite schists, garnet-mica quartzites and quartz schists. A thin but conspicuous light-weathering unit of quartzite and quartz-rich schist in which certain parts are characterised by a pale blue to grey, almost pure quartz rock, occurs near the top of the sequence. The whole succession is limited concordantly above by acid to basic, brown weathering hypersthene-bearing, commonly garnetiferous gneisses.

The orange to reddish-brown weathering quartzite and mica schists with garnet amphibolite, at the head of Inglefield Bredning (Dawes, 1972) were found to form extensive areas to the west around Bowdoin Fjord. The rocks have been deformed with the surrounding older (?) gneisses and have been involved in large-scale isoclinal folding and later deformation phases producing open folds. Large-scale recumbent isoclines at Hubbard Gletscher and to the east have given rise to several mountain profiles in which more resistent gneiss units overlie and cap multicoloured and recessive supracrustal rocks. The peculiar-shaped mountain, named Sugarloaf by Peary (1898), is a conspicuous example.

\section{Melville Bugt}

In 1978 , work was carried out between Kap York $\left(67^{\circ} \mathrm{W}\right)$ and Fisher Øer (62 W) (fig. 6$)$. The nunatak belt was investigated by helicopter traverses out of Savigsivik with occasional ground stops, while 10 days was spent in the coastal area using rubber dingies from the cutter $K$. J. V. Steenstrup. Ice conditions restricted the coastal work to more or less the islands and tips of the peninsulas.

The complex of highly-deformed gneisses, schists and supracrustal rocks of the Kap York - Savigsivik region (Dawes, 1976) was traced eastwards in the nunatak belt between $65^{\circ}$ and $63^{\circ} \mathrm{W}$. Here the majority of the complex is composed of grey-weathering biotite and hornblende gneisses in amphibolite facies. Several areas of more leucocratic granitic gneiss and granites, in places porphyroblastic, have gradational contacts to the gneisses.

Parts of the gneisses, e.g. in the regions of Helland Gletscher and Mohn Gletscher, are 


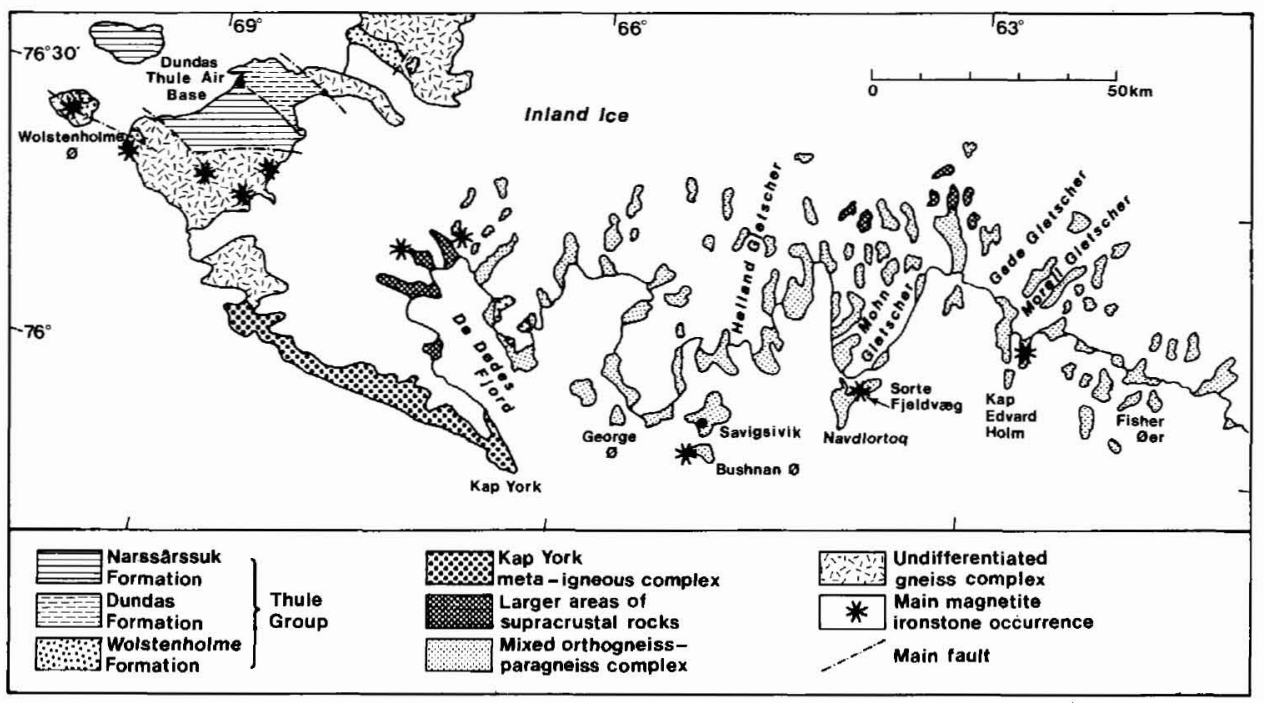

Fig. 6. Geological sketch map of the Dundas-Melville Bugt region showing the known locations of the magnetite ironstone formation.

characterised by abundant, thin amphibolite layers and boudins that show the effect of intense deformation being broken up and folded into intricate patterns. Certain nunataks expose thicker successions of amphibolites (?metavolcanics) while several supracrustal successions outcropping on the northern nunataks, e.g. to the north-west of Gade Gletscher, contain rusty-weathering schists, quartz-rich paragneisses, and garnet quartzites and amphibolites. These rocks have been involved in the large-scale isoclinal folding and later deformation of the complex.

In the coastal areas, the gneiss complex appears to contain less amphibolitic material. However, at several places important metasedimentary successions exist and some of these are characterised by being associated with magnetite-bearing rocks. For example, on Bushnan $\varnothing$ (where Bøggild, 1953, reported banded ironstone) a succession of quartz-rich gneiss and schist occurs containing several units of magnetite-rich melanocratic gneiss and magnetite-bearing quartzite. On the peninsula in front of Morell Gletscher a thick unit of garnet-biotite-sillimanite schists contains intercalated layers of rusty-weathering magnetite-quartz rocks, garnet amphibolite, pelitic schists and porphyroblastic paragneiss. In contrast, other metasedimentary layers elsewhere within the gneisses, can be relatively inconspicuous perhaps only a few metres thick. Throughout the region investigated, for example at George $\varnothing$, Navdlortoq, Kap Edvard Holm and Fisher Øer, basic to intermediate rocks of igneous aspect (dolerite to diorite) outcrop over large areas associated with, and having gradational contacts to, the gneisses. On Fisher Øer a spectacular transition exists from brown-weathering metadolerite forming the summit of the eastern island, through foliated basic rocks to hornblende gneiss, in which all primary igneous features have been obliterated. 
Age and correlation

The 1978 field work has demonstrated that large areas of the gneiss complex in northern Melville Bugt have been derived from igneous rocks of comparable age to the Kap York meta-igneous complex (Dawes, 1975). The similarities that are now apparent between the regional geology of Melville Bugt and Inglefield Land (the presence in both areas of supracrustal successions, meta-igneous rocks and derived gneisses) suggest a similar evolution for the two regions. Hence, the Etah Group, invaded by the Etah meta-igneous complex, are possible age equivalents to the supracrustal units and the Kap York meta-igneous complex. The Etah meta-igneous complex has suffered metamorphism and polyphase deformation in Hudsonian time (Larsen \& Dawes, 1974). Thus, in all probability the gneisses mapped in Melville Bugt are of Proterozoic age.

On the other hand, Archaean basement outcrops in the Upernavik region $\left(73^{\circ} \mathrm{N}\right)$, and possibly farther north in northern West Greenland (Escher \& Stecher, 1978), so that a major geological boundary exists somewhere in Melville Bugt separating this southern Archaean terrain from the essentially younger suite of gneisses of northern Melville Bugt.

The age of the supracrustal units now recognised in Prudhoe Land is more uncertain. The similar supracrustal sequence of unknown age at Inglefield Bredning overlie what has been regarded as an older gneissic basement (Dawes, 1972) and these gneissic rocks are thought to compose much of the central Thule District. Whether or not these gneisses represent all or in part Archaean material is as yet unknown.

\section{Proterozoic Thule Group}

Inglefield Land - Prudhoe Land

From four flycamps, at Rensselaer Bugt, Force Bugt, Sonntag Bugt and Morris Jesup Gletscher (fig. 5), profiles were measured through the unmetamorphosed strata that overlie the Precambrian basement with profound unconformity.

The basal Cambrian, cross-bedded sandstone formation containing Cruziana and Scolithos, recognised in 1977 overlying the Proterozoic strata in the Rensselaer Bugt area (Peel, 1978), thins westwards and at Kap Inglefield it is about $15 \mathrm{~m}$ thick. To the south it apparently peters out concurrently with the overlying Cape Leiper and Cape Ingersoll Formations although the exact aerial limits of the sandstone formation were not determined. The name Rensselaer Bay Formation (Troelsen, 1950) is here restricted to the Proterozoic succession.

Over large areas the boundary between the basal Cambrian strata and the Rensselaer Bay Formation is a simple disconformity and most difficult to position in the steep cliffed coastal sections. However, where the upper part of the Rensselaer Bay Formation is reached by basic igneous material, the erosional nature of the boundary is more easily demonstrable. Thus, to the west of Rensselaer Bugt a thin dolerite sill which forms discontinuous exposure, shows an irregular weathered top surface and lacks the otherwise ubiquitous upper chilled contact.

The Rensselaer Bay Formation at Rensselaer Bugt is characterised by dominantly red and green, with minor buff coloured, shallow water sandstones, shales with mud cracks and with some conspicuous stromatolitic dolomite beds. Certain horizons contain abundant and 
Fig. 7. Faulted exposures of the Lower Thule Group in the northern part of the Thule Basin at Radcliffe Pynt, Sonntag Bugt. A red recessive formation (marked B), regarded as the stratigraphic equivalent of the Rensselaer Bay Formation of Inglefield Land, is underlain and overlain by un-named buff sandstone formations (marked $\mathrm{A}$ and $\mathrm{C}$ ). Several basic sills are present.

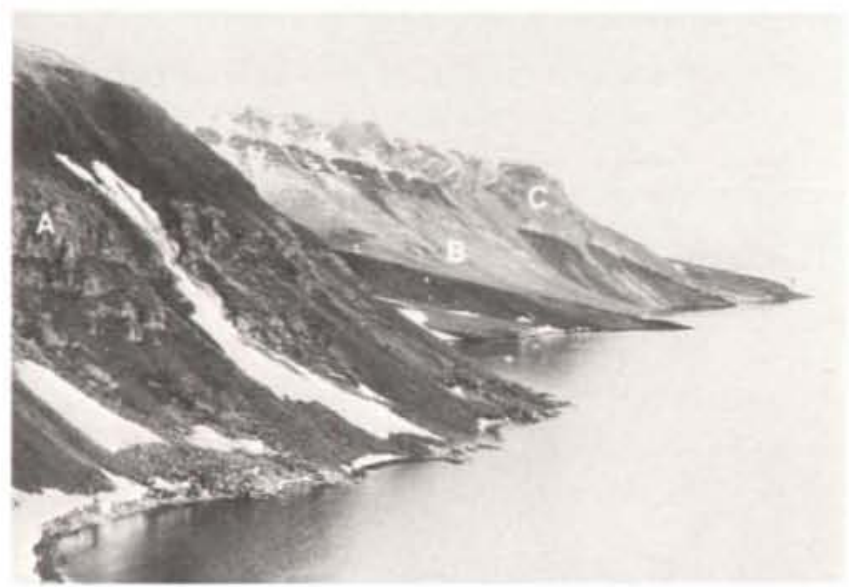

well-preserved worm-like trace fossils. At Rensselaer Bugt the formation varies from about $130 \mathrm{~m}$ at the outer coast to perhaps locally $200 \mathrm{~m}$ further inland where there is appreciable basement relief. In Force Bugt the formation is about $120 \mathrm{~m}$ thick although a basic sill consistently occurs at the upper contact of the sequence and hides the precise thickness. At Hatherton Bugt and to the south the Rensselaer Bay Formation is overlain by a buff-weathering formation of cross-bedded sandstones and grits that at least in the lower part is invaded by Proterozoic dolerite sills. This sandstone unit was referred by Cowie (1970) to the Sverdrup Member of the Rensselaer Bay Formation. However, since this member in its type locality in Ellesmere Island contains Scolithos (Christie, 1967, and personal communication) and is of Cambrian age, this practise should be discontinued.

The bipartite Proterozoic sequence can be traced uninterruptedly as far south as the peninsula north of Kap Alexander where the entire sequence lying above the exposed Precambrian basement is at least $300 \mathrm{~m}$ thick. Dodge Gletscher, north of Kap Alexander presumably marking a WNW fault line, separated this two-fold sequence from the substantially thicker succession of the Thule Basin.

The bipartite sequence can be recognised in the Thule Basin between Sonntag Bugt and Morris Jesup Gletscher (as part of the Wolstenholme Formation, fig. 7) being underlain by older clastic rocks, mainly buff-weathering but with some red beds, as well as by an extrusive volcanic unit. Many of these clastic rocks are quartz sandstones with some grits and conglomerates, characterised by cross-bedding and ripple marks. Their lithological aspect indicates a near-shore depositional environment. Thus the pale pink to buff sandstones at least $130 \mathrm{~m}$ thick that form the coast between Kap Alexander and Sonntag Bugt, display herringbone cross-bedding indicating bimodal current directions which suggests strong tidal influence.

The volcanic unit is restricted to the northern and central part of the Thule Basin. It can be traced throughout northern Prudhoe Land from its northernmost exposure east of Sonntag Bugt to Robertson Fjord, and onto Northumberland $\emptyset$. 


\section{Northumberland $\varnothing$}

On Northumberland $\varnothing$ (fig. 5) parts of the Wolstenholme Formation were investigated and sections measured. This part of the Thule Group is remarkably similar in many aspects to the Proterozoic strata exposed in south-eastern Ellesmere Island that have also been referred to the Thule Group (Christie, 1972; Frisch et al., 1978). Certain detailed correlation is now possible across Smith Sund and particularly noteworthy for comparative purposes is a 15 to $20 \mathrm{~m}$ unit of dark shales, dolomites and dolomitic limestones with characteristic stromatolites, that was investigated in 1978, overlying the volcanic unit (unit 2 of Dawes, 1976). These rocks are extremely similar in lithology and have an identical stratigraphical position to a shale-carbonate sequence in Ellesmere Island (T. O. Frisch, personal communication). In addition, the volcanic unit in both lands is composed of similar flows and sills, agglomerates, and intercalated red and purple siltstones.

\section{North Star Bugt - Dundas}

Certain profiles in the Dundas Formation and the Narssârssuk Formation were measured in the vicinity of North Star Bugt and Dundas (fig. 5).

The Dundas Formation at Dundas Fjeld is composed of a thin-bedded, dark-weathering sequence over $200 \mathrm{~m}$ thick composed of black, dark grey and green, fine- to medium-grained sandstones, siltstones and shales, dolomitic limestone, with green and dark grey chert and minor stromatolites. Several coarsening-upwards sequences are recognisable near the base of the section. Thin evaporite horizons occur and many bedding surfaces are coated by gypsum. In the middle to upper part of the section many laminated shale beds are characterised by having subconcordant veins of pure fibrous gypsum.

The Narssârssuk Formation is a thick, multicoloured sequence restricted to the southern part of the Thule Basin being characterised by the cyclic alteration of dolomite, limestone, fine-grained sandstone, shale and red siltstone (Davies et al., 1963). In 1978 the lower part of the formation was studied at several sections immediately south of Thule Air Base.

The oldest rocks discovered consist of about $70 \mathrm{~m}$ of light to dark grey dolomites and siltstones, varying from porous homogeneous dolomite to thin and wavy bedded, often well-laminated dolomite and calcareous siltstone. Wavy or domed-shaped stromatolites characterise some units. These pass upwards into the typical lithology of the Lower Red Member, with each cycle topped by red siltstone or fine-grained sandstone.

Of particular interest is the presence of evaporite, predominantly gypsum, that occurs in places throughout the lower part of the formation (Lower Red Member), as thin horizons, fracture infillings and as anastomosing veins, as well as orange-coloured nodules several centimetres long. Some thin cherts and cherty dolomite also occur.

The boundary between the Dundas Formation and the Narssârssuk Formation lies beneath the wide Quaternary-filled valley in which Thule Air Base is situated. Thus the stratigraphical relation between the formations is uncertain although the regional structure suggests that the Narssârssuk Formation is all or in part of younger age. The presence, particularly in the upper part of the Dundas Formation, of evaporite, chert, dolomite and stromatolites, suggests a gradation to the lithology of the Narssârssuk Formation. Both formations indicate deposition in shallow water environments and they may represent as- 
sociated sedimentary facies varying from perhaps deltaic or coastal plain conditions (Dundas Formation) to rather stable lacustrine or lagoonal conditions (Narssârssuk Formation). The presence of evaporites and primary gypsum nodules, plus the overall red colouration of the Narssârssuk Formation, indicates a warm and evaporitic environment, with periodic fluctuations of the shallow, quiet water conditions, producing the cyclic deposits - depositional conditions comparable to those of modern sabkhas.

\section{Economic geology}

Black sands, ilmenite and ?magnetite bearing, were sampled at Sonntag Bugt ( $\left.78^{\circ} \mathrm{N}\right)$ (fig. 5) and near Kap Edvard Holm ( $76^{\circ} \mathrm{N}$ ) (fig. 6), thus extending the area within the Thule District known to be of potential economic interest (Cooke, 1978). However, no extensive new black sand localities were discovered in 1978.

Magnetite-rich rocks (gneisses, schists and quartzites), as well as typical banded ironstone, were located in several places in Melville Bugt and these localities together with those known previously (fig. 6) indicate a large iron province that warrants further investigation. The most well-developed banded ironstones, composed of intercalated discrete bands of quartz and magnetite several millimetres thick, were located on Sorte Fjeldvæg, where units up to about $2 \mathrm{~m}$ thick are intercalated with garnet amphibolite and leucocratic gneiss. Elsewhere the magnetite-rich rocks can be associated with metasedimentary supracrustal rocks and paragneisses.

The evaporites in the Dundas and Narssârssuk Formations located in 1978 are relatively thin beds, with the largest being subconcordant veins of fibrous gypsum that reach up to 10 $\mathrm{cm}$ in thickness. It is noteworthy, however, that Davies et al. (1963) describe thicker evaporite beds from borehole logs in the Narssârssuk Formation.

\section{Acknowledgements}

Erik Arnholtz (Thule Air Base) is thanked for indispensable liaison of the field activity and for general help, while Kurt Thomsen (Thule) is thanked for able assistance in the field.

\section{References}

Bøggild, O. B. 1953: The mineralogy of Greenland. Meddr Grønland 149,3, 442 pp.

Christie, R. L. 1967: Bache Peninsula, Ellesmere Island, Arctic Archipelago. Mem. geol. Surv. Can.347, $63 \mathrm{pp}$.

Christie, R. L. 1972: Central Stable Region. In Christie, R. L. et al., The Canadian Arctic Islands and the Mackenzie region. 24 Congr. geol. int. Canada. Guidebook field excursion A66, 40-87.

Cooke, H. R. 1978: Mineral reconnaissance of the Thule district, North-West Greenland. Rapp. Grønlands geol. Unders. 90, 17-22.

Cowie, J. W. 1970: The Cambrian of the North American Arctic Regions. In Holland, C. H. (edit.) Cambrian of the New World, 325-383. London: Interscience.

Davies, W. E., Krinsley, D. B. \& Nicol, A. H. 1963: Geology of the North Star Bugt area, Northwest Greenland. Meddr Grønland 162,12, 68 pp.

Dawes, P. R. 1972: Precambrian crystalline rocks and younger sediments of the Thule district, North Greenland. Rapp. Grønlands geol. Unders. 45, 10-15. 
Dawes, P. R. 1975: Reconnaissance of the Thule Group and underlying basement rocks between Inglefield Bredning and Melville Bugt, North Greenland. Rapp. Gronlands geol. Unders. 75, 34-38.

Dawes, P. R. 1976: 1:500 000 mapping of the Thule district, North-West Greenland. Rapp. Grønlands geol. Unders. 80, 23-28.

Escher, J. C. \& Stecher, O. 1978: Precambrian geology of Upernavik - Red Head region $\left(72^{\circ} 15^{\prime}-75^{\circ} 15^{\prime} \mathrm{N}\right)$, northern West Greenland. Rapp. Grønlands geol. Unders. 90, 23-26.

Frisch, T., Morgan, W. C. \& Dunning, G. R. 1978: Reconnaissance geology of the Precambrian Shield on Ellesmere and Coburg Islands, Canadian Arctic Archipelago. Pap. geol. Surv. Can. 78-1A, 135-138.

Larsen, O. \& Dawes, P. R. 1974: K/Ar and Rb/Sr age determinations on Precambrian crystalline rocks in the Inglefield Land-Inglefield Bredning region, Thule district, western North Greenland. Rapp. Grønlands geol. Unders. 66, 4-8.

Peary, R. E. 1898: Northward over the "Great Ice”. 1, 521 pp. New York: Frederick A. Stokes.

Peel, J. S. 1978: Geological investigations in Lower Palaeozoic terrain of northern Greenland between $78^{\circ} 30^{\prime} \mathrm{N}$ and $81^{\circ} 30^{\prime} \mathrm{N}$. Rapp. Grønlands geol. Unders. 90, 14-16.

Troelsen, J. C. 1950: Contributions to the geology of Northwest Greenland, Ellesmere Island and Axel Heiberg Island. Meddr Grønland 149,7, 86 pp.

\title{
Field work on Precambrian anorthosite and contact rocks, Smithson Bjerge, Inglefield Bredning, North-West Greenland
}

\begin{abstract}
A. Nutman
This report gives an account of geological investigations and 1:25000 scale mapping of Precambrian rocks of Smithson Bjerge, at the head of Inglefield Bredning, about $150 \mathrm{~km}$ north-east of Thule Air Base. Previous work on this area was restricted to a few days of reconnaissance work in 1971 and several helicopter landings in 1975 (Dawes, 1972, and personal communication, 1978). Table 1 gives the principle geological events of the area and results of the mapping are given in outline in fig. 8 .
\end{abstract}

\section{Geological Divisions \\ Qaqujârssuaq anorthosite}

The northern half of the area is underlain by a generally uniform anorthosite body. Hornblende, locally with cores of pyroxene, is the dominant ferromagnesian mineral, garnet also occurs locally. The ferromagnesian minerals often occur with fine-grained plagioclase as groundmass to recrystallised plagioclases 5 to $50 \mathrm{~mm}$ in diameter, a relation interpreted as a relict igneous texture. Cyclic variation in the proportions of ferromagnesian mineral content is fairly common, giving the rock a moderately well-defined compositional banding.

More than 90 per cent of the anorthosite complex is true anorthosite, the remainder being leucogabbro and subordinate gabbro. Leucogabbro is most abundant about 1 to $2 \mathrm{~km}$ from 